\title{
Remembering Ben Barres
}

\author{
Arthur Butt ${ }^{1, *}$, Maiken Nedergaard ${ }^{2,3, *}$ and Alexei Verkhratsky ${ }^{4,5, *}$
}

1 Institute of Biomedical and Biomolecular Sciences, School of Pharmacy and Biomedical Science, University of Portsmouth, Portsmouth, PO1 2DT, UK

2 Center for Basic and Translational Neuroscience, Faculty of Health and Medical Sciences, University of Copenhagen, Copenhagen 2200, Denmark

3 Center for Translational Neuromedicine, University of Rochester Medical Center, Rochester, NY 14642, USA

4 Faculty of Life Sciences, University of Manchester, Manchester M13 9PT, UK

5 Achúcarro Basque Center for Neuroscience, IKERBASQUE, Basque Foundation for Science, Bilbao 48011, Spain

* Correspondence: Arthur.butt@port.ac.uk (A.B.); Maiken_Nedergaard@URMC.Rochester.edu (M.N.); Alexej.Verkhratsky@manchester.ac.uk (A.V.)

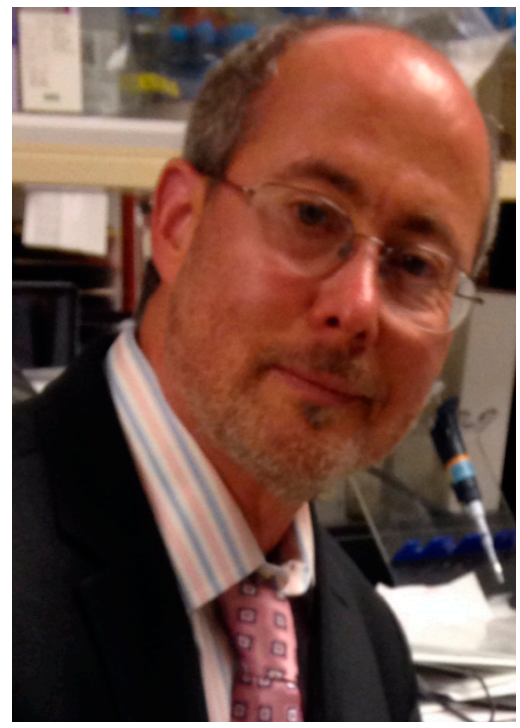

Ben Barres (1954-2017).

Ben Barres, who was at the heart of glial cell physiology for over 30 years, died aged 63 on December 27, 2017. Ben's first paper provided a classical description of ion channels in cultured astrocytes and oligodendrocytes, published in the journal Glia in 1988 [1]. Ben went on to work at University College London on oligodendrocyte development with Martin Raff, and one of Ben's enduring findings is that oligodendroglial precursors are regulated by axonal activity, thus setting the stage for axon-glia bilateral communication, which remains central to current thinking [2,3]. Next, Ben moved to Stanford and in 1997 made the seminal discovery of astroglia-dependent synaptogenesis. More recently, Ben has been a frontrunner in the "omic" revolution by creating a glial transcriptome database that has begun to decipher neuroglial heterogeneity on a molecular level [4]. In the last decade, Ben was increasingly interested in pathology and his final fundamental discovery was the identification of specific forms of reactive astrocytes that can be either neuroprotective or neurodestructive [5]. Ben will be remembered for his pioneering work in taking glial cells from the "dark ages" of passive structural elements to being at the very core of brain function.

Among Ben's key attributes were his ability to develop and exploit new methodologies, his clarity of thought, and his capacity to design and execute elegantly simple critical experiments. Ben started 
his journey in the nascent days of glial physiology, when cell culture was in its infancy and the first patch-clamp experiments were beginning to show that glial cells express many ion channels and neurotransmitter receptors [6-10]. Ben tackled the problem of isolating glial cells using innovative panning techniques and performed the first detailed investigation of voltage-gated sodium and calcium channels in astrocytes and oligodendrocyte lineage cells [11-13]. These findings were truly revolutionary, since these expression of voltage-gated ion channels had hitherto been an exclusive property of neurones. Ben's work helped overturn this misconception and laid down the tracks of his studies on glial cell physiology.

Ben's journey continued in London in the early 1990s, when he went to work with Martin Raff, the frontrunner of glial cell biology at that time. In London, Ben's studies focused on the development of the oligodendroglial lineage and he showed that axonal activity controls proliferation and survival of oligodendroglial precursors [2,3]. These early observations developed further when Ben discovered that oligodendroglial development is regulated not only by neuronal factors but also by astrocytes that instruct oligodendrocytes to lean towards axons [14].

After returning to Stanford, Ben's focus switched to astrocytes and in 1997 (with Frank Pfrieger) he made what is perhaps his most important contribution to glial cell biology-the demonstration that neuronal synaptogenesis is regulated by astrocytes. As was so often the case with Ben, the critical experiment was elegantly simple - they monitored spontaneous synaptic activity in neurones cultured alone or with astrocytes and found that synaptic activity increased many-fold in neurone-astrocyte co-cultures $[15,16]$. Astroglia-dependent synaptogenesis became a recurrent theme in Ben's research and he was the first to find a role for thrombospondins secreted by astroglia in promoting synaptic formation in the context of physiology [17] and pathology [18]. Several years later, Ben described further sets of astroglia-derived factors that control synaptogenesis. First, he identified the actions of hevin, which potentiates genesis of excitatory synapses, and SPARC (secreted protein acidic and rich in cysteine), which inhibits hevin-induced synaptogenesis. Subsequently, he showed that astroglia-derived glypicans 4 and 6 promote formation of excitatory synapses [19]. All these studies have been conceptualized in several important reviews [20,21], which portray astrocytes as the major regulators of synaptic formation, maturation and elimination.

In 2008, Ben published the transcriptome database for astrocytes and oligodendrocytes, compared with neurones, which begun to decipher neuroglial heterogeneity on a molecular level [4]. These databases were further updated in 2014 [22] and 2016 [23] and have rapidly become a worldwide tool for glial researchers-the 2008 paper has been cited more than 1300 times. Ben went on to examine the genomic "fingerprint" of astrocytes in different neuropathologies, which led him to the definition of "neuroprotective" and "neurodestructive" phenotypes of astrocyte in neuropathology [5]. He proposed that it was the balance between these two extreme forms that may define the progression and outcome of the pathology. These findings provide a foundation that will stimulate exciting new avenues of research over the coming years.

Ben was aware of his fatal disease for almost 2 years. Perhaps most impressive about him was how he tackled his disease. His monthly update on his treatment in "Caringbridge" was like reading a science report. Ben relentlessly supported young investigators and regarded his trainees as family. In his last 6 months, Ben spent a large amount of time transferring grants and otherwise making sure that his team could continue their work uninterrupted by his death. Ben will be remembered by the glial cell community in many ways. He was not shy about expounding his views and his ability to quickly grasp the key point and ask insightful questions was known to all in the field. His questions to a speaker have in many cases led to new directions of a study. Ben was the bedrock of glial cell research and neuroscience is the poorer for his passing.

\section{References}

1. Barres, B.A.; Chun, L.L.; Corey, D.P. Ion channel expression by white matter glia: I. Type 2 astrocytes and oligodendrocytes. Glia 1988, 1, 10-30. [CrossRef] [PubMed] 
2. Barres, B.A.; Jacobson, M.D.; Schmid, R.; Sendtner, M.; Raff, M.C. Does oligodendrocyte survival depend on axons? Curr. Biol. 1993, 3, 489-497. [CrossRef]

3. Barres, B.A.; Raff, M.C. Proliferation of oligodendrocyte precursor cells depends on electrical activity in axons. Nature 1993, 361, 258-260. [CrossRef] [PubMed]

4. Cahoy, J.D.; Emery, B.; Kaushal, A.; Foo, L.C.; Zamanian, J.L.; Christopherson, K.S.; Xing, Y.; Lubischer, J.L.; Krieg, P.A.; Krupenko, S.A.; et al. A transcriptome database for astrocytes, neurons, and oligodendrocytes: A new resource for understanding brain development and function. J. Neurosci. 2008, 28, 264-278. [CrossRef] [PubMed]

5. Liddelow, S.A.; Guttenplan, K.A.; Clarke, L.E.; Bennett, F.C.; Bohlen, C.J.; Schirmer, L.; Bennett, M.L.; Munch, A.E.; Chung, W.S.; Peterson, T.C.; et al. Neurotoxic reactive astrocytes are induced by activated microglia. Nature 2017, 541, 481-487. [CrossRef] [PubMed]

6. Bevan, S.; Chiu, S.Y.; Gray, P.T.; Ritchie, J.M. The presence of voltage-gated sodium, potassium and chloride channels in rat cultured astrocytes. Proc. $R$ Soc. Lond. B Biol. Sci. 1985, 225, 299-313. [CrossRef] [PubMed]

7. Bowman, C.L.; Kimelberg, H.K. Excitatory amino acids directly depolarize rat brain astrocytes in primary culture. Nature 1984, 311, 656-659. [CrossRef] [PubMed]

8. Kettenmann, H.; Backus, K.H.; Schachner, M. Aspartate, glutamate and gamma-aminobutyric acid depolarize cultured astrocytes. Neurosci. Lett. 1984, 52, 25-29. [CrossRef]

9. Kettenmann, H.; Okland, R.K.; Lux, H.D.; Schachner, M. Single potassium channel currents in cultured mouse oligodendrocytes. Neurosci. Lett. 1982, 32, 41-46. [CrossRef]

10. Kettenmann, H.; Schachner, M. Pharmacological properties of gamma-aminobutyric acid-, glutamate-, and aspartate-induced depolarizations in cultured astrocytes. J. Neurosci. 1985, 5, 3295-3301. [PubMed]

11. Barres, B.A. Glial ion channels. Curr. Opin. Neurobiol. 1991, 1, 354-359. [CrossRef]

12. Barres, B.A.; Koroshetz, W.J.; Chun, L.L.; Corey, D.P. Ion channel expression by white matter glia: The type-1 astrocyte. Neuron 1990, 5, 527-544. [CrossRef]

13. Barres, B.A.; Koroshetz, W.J.; Swartz, K.J.; Chun, L.L.; Corey, D.P. Ion channel expression by white matter glia: The o-2a glial progenitor cell. Neuron 1990, 4, 507-524. [CrossRef]

14. Meyer-Franke, A.; Shen, S.; Barres, B.A. Astrocytes induce oligodendrocyte processes to align with and adhere to axons. Mol. Cell. Neurosci. 1999, 14, 385-397. [CrossRef] [PubMed]

15. Pfrieger, F.W.; Barres, B.A. Synaptic efficacy enhanced by glial cells in vitro. Science 1997, 277, $1684-1687$. [CrossRef] [PubMed]

16. Ullian, E.M.; Sapperstein, S.K.; Christopherson, K.S.; Barres, B.A. Control of synapse number by glia. Science 2001, 291, 657-661. [CrossRef] [PubMed]

17. Christopherson, K.S.; Ullian, E.M.; Stokes, C.C.; Mullowney, C.E.; Hell, J.W.; Agah, A.; Lawler, J.; Mosher, D.F.; Bornstein, P.; Barres, B.A. Thrombospondins are astrocyte-secreted proteins that promote CNS synaptogenesis. Cell 2005, 120, 421-433. [CrossRef] [PubMed]

18. Liauw, J.; Hoang, S.; Choi, M.; Eroglu, C.; Choi, M.; Sun, G.H.; Percy, M.; Wildman-Tobriner, B.; Bliss, T.; Guzman, R.G.; et al. Thrombospondins 1 and 2 are necessary for synaptic plasticity and functional recovery after stroke. J. Cereb. Blood Flow Metab. 2008, 28, 1722-1732. [CrossRef] [PubMed]

19. Allen, N.J.; Bennett, M.L.; Foo, L.C.; Wang, G.X.; Chakraborty, C.; Smith, S.J.; Barres, B.A. Astrocyte glypicans 4 and 6 promote formation of excitatory synapses via glua1 AMPA receptors. Nature 2012, 486, 410-414. [CrossRef] [PubMed]

20. Eroglu, C.; Barres, B.A. Regulation of synaptic connectivity by glia. Nature 2010, 468, 223-231. [CrossRef] [PubMed]

21. Chung, W.S.; Barres, B.A. The role of glial cells in synapse elimination. Curr. Opin. Neurobiol. 2012, 22, 438-445. [CrossRef] [PubMed]

22. Zhang, Y.; Chen, K.; Sloan, S.A.; Bennett, M.L.; Scholze, A.R.; O’Keeffe, S.; Phatnani, H.P.; Guarnieri, P.; Caneda, C.; Ruderisch, N.; et al. An RNA-sequencing transcriptome and splicing database of glia, neurons, and vascular cells of the cerebral cortex. J. Neurosci. 2014, 34, 11929-11947. [CrossRef] [PubMed]

23. Zhang, Y.; Sloan, S.A.; Clarke, L.E.; Caneda, C.; Plaza, C.A.; Blumenthal, P.D.; Vogel, H.; Steinberg, G.K.; Edwards, M.S.; Li, G.; et al. Purification and characterization of progenitor and mature human astrocytes reveals transcriptional and functional differences with mouse. Neuron 2016, 89, 37-53. [CrossRef] [PubMed]

(C) 2018 by the authors. Licensee MDPI, Basel, Switzerland. This article is an open access article distributed under the terms and conditions of the Creative Commons Attribution (CC BY) license (http:/ / creativecommons.org/licenses/by/4.0/). 